\title{
A moderate microsampling in Laser Ablation Inductively Coupled Plasma Mass Spectrometry analysis of cultural heritage objects: a review
}

\author{
Barbara Wagner*, Olga Syta, Marek Sawicki \\ Faculty of Chemistry, Biological and Chemical Research Centre, University of Warsaw, \\ ul. Żwirki i Wigury 101, 02-089 Warsaw, Poland \\ * Corresponding author: barbog@chem.uw.edu.pl
}

\begin{abstract}
Laser Ablation Inductively Coupled Plasma Mass Spectrometry (LA-ICP-MS) is one of modern instrumental methods whose usage in the elemental analysis of cultural heritage objects has recently noticeably increased. The method requires almost no sample preparation and permits the direct analysis of solid samples, availing only minute amount of the material. Although they seem to be microdestructive, ablation processes remain usually within the scale acceptable for art historians, conservators, archaeologists and art curators; therefore, the capability to perform a multi-elemental, ultra trace and isotopic analysis can be introduced to studies of cultural heritage objects. The lack of appropriate matrix-matched certified reference materials or fractionation effects influencing the final quantitative results to a different extent is widely reported among the main limitations of LA-ICP-MS. Despite these constrains, LA-ICP-MS is a method that can be flexibly tuned to collect the desired elemental information and this paper brings together information about the successful application of this method in the analysis of diverse historical materials enabling researchers to build valuable knowledge about cultural heritage objects from all over the world.
\end{abstract}

Keywords: LA-ICP-MS, cultural heritage, archaeometry, works of art, elemental analysis

\section{Introduction}

The interest in archaeometric investigations and conservation science is growing every year and guidelines for selecting the optimum instrumental method are discussed in the literature. Van Grieken and Janssens [1] recalled Lahanier et al. [2], who published a list including a few desirable features of the best method of choice for the analysis of cultural heritage objects. The list included the multielemental character of direct measurements, low limits of detection, high sensitivity, versatility, universality, and a relatively short time of the analysis. The non-destructive character of the measurements was also pointed out by Lahanier.

The need to protect cultural heritage objects gives the priority to non-destructive measurements, although many of currently available methods can successfully utilize microscopic mass of samples [1,3]. Laser Ablation Inductively Coupled Plasma Mass Spectrometry (LA-ICP-MS) is one of modern 
instrumental methods whose need for sample consumption is reduced to absolute minimum [4-6]. All LA-ICP-MS measurements benefit from very sensitive elemental analysis and low limits of detection (down to $\mathrm{ngg}^{-1}$ ) [7-10], which allow the successful use of this method during provenance investigations [11-30], material identification [31-35], studies devoted to reconstructions of past technologies [36-42] and conservation research [43-46].

In this paper, we would like to discuss possible research scenarios based on the use of LA-ICP-MS, depending on the size of objects and agreement for sampling as well as a possibility of transportation to the laboratory. The number of papers devoted to the use of LA-ICP-MS for conservation science and archaeometry may be taken as a good indicator for the growing interest in the use of this method for the analysis of cultural heritage objects (Fig. 1).

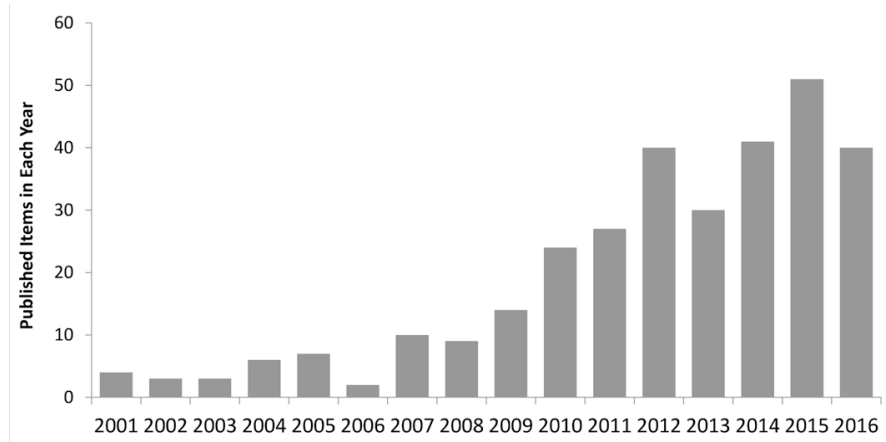

limits of detection (LOD) to the level of about $10 \mathrm{ng} \cdot \mathrm{g}^{-1}$ [47-49]. The later introduction of a commercially available instrumentation gave a new tool for: (i) direct analysis of solid; (ii) microanalysis; (iii) surface mapping and (iv) depth profiling of investigated materials $[10,50]$. The method has proven to be applicable for the analysis of literally all solids while elemental or isotopic information is needed.

Over 30 years of experience with laser ablation ICP-MS has resulted in rich literature about fundamentals and applications of the method based on a reliable recognition of its advantages and limitations $[4,50]$. The selection of cultural heritage as the research area has not changed the general procedural rules of using LA-ICP-MS; however, various analytical scenarios for using LA-ICP-MS during investigations of valuable objects were proposed.
Fig. 1. The number of papers published per each year according to the report generated by Web of Science.

\section{Introduction to LA-ICP-MS}

LA-ICP-MS was mentioned for the first time in 1985, when Gray described his preliminary study of using laser ablation with ICP-MS during investigation of rock samples [47]. His work extended the previous use of laser ablation combined with ICP-OES lowering

\section{LA-ICP-MS setup}

Typical LA-ICP-MS systems utilize laser ablation of solids in a neutral gas (argon and/or helium) atmosphere; the possibility to ablate solids in air is reported rarely [51]. While standard set-up is being used, a sample or an object is located in a moveable 
$\mathrm{x}-\mathrm{y}-\mathrm{z}$ stage and closed in a tightly sealed ablation cell continuously flushed with a carrier gas. A surface of a sample exposed to the laser beam can be observed in the real time with a CCD camera, allowing selection of the investigated area and proper laser beam focusing. The ablated aerosol is then transported by the carrier gas to the plasma and mass spectrometer (Fig. 2), where ions are separated according to their mass to-charge the investigated material, as well as parameters of the applied laser set up. Melting and boiling points, or ionization potentials of elements of interest, might also have an influence on ablation processes leading to their different course during the micro-sampling of solids [55-57]. Occurring differences were defined as fractionation, meaning the sum of non-stoichiometric processes changing the analytical response of signals if compared

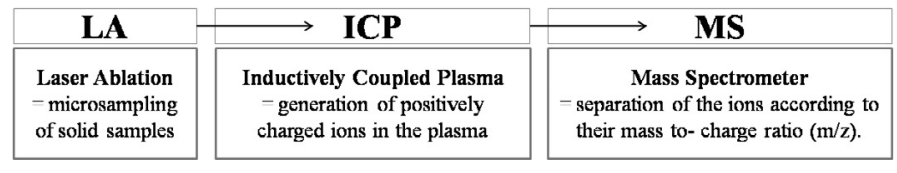

Fig. 2. The scheme of a typical LA-ICP-MS system. ratio $(\mathrm{m} / \mathrm{z})[5,50,52]$. There are no specific technical solutions of LA-ICP-MS setups especially designed for cultural heritage objects investigations; however, some systems facilitating microsampling of precious items were suggested in the literature $[53,54]$.

Laser ablation is effective practically for all solid materials; nevertheless, the course of the process depends on the number of factors related to chemical and physical properties of to the real stoichiometry of investigated samples [58]. The reliable quantification is challenging, yet achievable by using shorter lasers wavelengths (Table 1), shorter pulse durations and optimized power densities according to the actual knowledge about LA-ICP-MS measurements [8, 52, 59-66].

Lasers emitting shorter wavelengths (193 $\mathrm{nm}$ ) together with shorter pulse durations (fs) can reduce fractionation and would be

Table 1. Selected lasers used in LA-ICP-MS measurements

\begin{tabular}{cccc}
\hline Wavelength $(\mathrm{nm})$ & \multicolumn{2}{c}{ Laser type } & Pulse duration \\
\hline 1064 & Nd:YAG & Solid state & $\mathrm{ns}$ \\
$650-1100$ & Ti:Sapphire & Solid state & $\mathrm{fs}$ \\
694 & Ruby & Solid state & $\mathrm{ns}$ \\
532 & $\mathrm{Nd}: Y A G$ & Solid state & $\mathrm{ns}$ \\
355 & $\mathrm{Nd}: Y A G$ & Solid state & $\mathrm{ns}$ \\
308 & $\mathrm{XeCl}$ & Gas excimer & $\mathrm{ns}$ \\
$266^{*}$ & $\mathrm{Nd}: Y A G$ & Solid state & ns \\
248 & KrF & Gas excimer & ns \\
$213^{*}$ & $\mathrm{Nd}: Y A G$ & Solid state & ns \\
193 & $\mathrm{Nd}: Y A G$ & Solid state & ns \\
$193^{*}$ & ArF & Gas excimer & ns \\
157 & $\mathrm{~F}_{2}$ & Gas excimer & ns
\end{tabular}

*) The lasers most commonly used to ablate cultural heritage objects for ICP-MS analysis. 
preferably used during quantitative elemental analysis; however, the ablation with the use of $\mathrm{Nd}: Y A G$ ns lasers emitting either $\lambda=266 \mathrm{~nm}$ or $\lambda=213 \mathrm{~nm}$ is still popular. Femtosecond lasers are less commonly used [16] for investigations of cultural heritage objects than the nanosecond ones.

To minimize the effects of fractionation Brostoff et al. [16] used fs-LA-ICP-MS in provenance studies of rare ancient gold artifacts. The main groups of the objects were distinguished on the basis of elemental composition and variable content of $\mathrm{Ag}, \mathrm{Pd}, \mathrm{Pt}$ or $\mathrm{Sn}, \mathrm{Cu}$ and $\mathrm{Zn}$. The multielemental information obtained by means of LA-ICP-MS was important to support historical, technical and stylistic evaluation of the investigated gold objects and was used for matching the fragments by origin of manufacture with a good precision and accuracy.

The appropriate calibration for quantification of multielemental LA-ICP-MS measurements remains a challenging task mainly due to the strong dependence of ablation processes on manifold physicochemical properties of solids. Properly selected reference materials with the known content of elements of interest allow the reliable calibration and accurate determination of the elemental composition of investigated objects (Table 2). Three possible calibration approaches can be used to quantify LA-ICP-MS signals. The most popular calibration approach is based on the use of solid matrix-matched reference materials [61, 67], while dual introduction of standard solutions together with the ablated matter [68-70] or direct ablation of liquid standards [71-73] are less commonly applied.

There are many commercially available and well characterized solid reference materials $[43,74,112,113,134-138]$ which can be used in LA-ICP-MS investigations (Table 2).
Only these of the composition and the structure properly matching analyzed materials can offer accurate quantification by ensuring the consistency of ablation processes for both: the sample and the standard [14]. A careful selection of the matrix-matched standards would provide accurate results of LA-ICP-MS measurements together with internal standardization (IS), which is recommended to reduce matrix effects and correct differences in ablation efficiency of samples $[61,139]$. If no adequate standards are available, non-matrix matched calibration approaches could be applied with normalization to $100 \%$ procedure [140-143] and allow for collecting information about major, minor and trace elemental composition of investigated objects. In all cases, the results of LA-ICP-MS measurements should be checked according to the quality control protocol.

\section{LA-ICP-MS in relation to destructiveness and invasiveness of investigations of cultural heritage objects}

Many authors pointed out that LA-ICP-MS causes only those damages that are not visible to the naked eye $[32,54,76,93,113,144$, 145]. A laser beam energy may be focused on an area with diameters of about a few up to several hundred micrometers limiting the post-ablation marks to the selected location. The spot ablation means the micro-sampling of the material from a single point, while rastering or line/multiline ablation allows assessment of elemental/isotopic spatial distribution over a surface of a sample [179]. An opportunity for selective analysis of surface or sub-surface domains is particularly important during investigations of heterogeneous objects, corroded or covered with patina. 
Table 2. Reference materials used in LA-ICP-MS quantitative analysis of cultural heritage objects

\begin{tabular}{|c|c|}
\hline Sample & Reference materials used \\
\hline $\begin{array}{l}\text { Glass } \\
{[13,18,22,26,74-92]}\end{array}$ & $\begin{array}{l}\text { National Institute of Standards and Technology: 610, 612, } 614 \text { (trace elements in } \\
\text { glass) } \\
\text { Corning Museum of Glass: A, B, C, D } \\
\text { U.S. Geological Survey: BCR-2G, BHVO-2G, BIR-1G (basalt glasses) } \\
\text { Society of Glass Technology: 2, 3, 4, 5, 6, 7, 8, } 9\end{array}$ \\
\hline $\begin{array}{l}\text { Obsidian } \\
{[12,93-98]}\end{array}$ & $\begin{array}{l}\text { National Institute of Standards and Technology: 610, } 612 \\
\text { Corning Museum of Glass: B, D } \\
\text { U.S. Geological Survey: BCR-2G } \\
\text { Natural obsidians from: Glass Butte (USA), Sierra de Pachuca (Mexico), Wekwok } \\
\text { (Papua New Guinea) }\end{array}$ \\
\hline $\begin{array}{l}\text { Ceramic } \\
{[23,29,30,33,35,36} \\
40,53,99-111]\end{array}$ & $\begin{array}{l}\text { National Institute of Standards and Technology: } 679 \text { (brick clay), 1633a (coal fly } \\
\text { ash); 610, 612, 614, } 1412 \text { (glasses) } \\
\text { Corning Museum of Glass: B, D } \\
\text { Missouri University Research Reactor Center: New Ohio Red Clay } \\
\text { U.S. Geological Survey: BIR1 (basalt); AGV2 (andesite); GSP2 (granodiorite); } \\
\text { RGM1 (rhyolite); BCR-2G, BHVO-2G (basalt glasses) } \\
\text { National Institute for Metallurgy: NIM-L (lujavrite) } \\
\text { Institute for Reference Materials and Measurements: BCR-126A (lead glass) } \\
\text { ANRT reference material: FK-N (potash feldspar) }\end{array}$ \\
\hline $\begin{array}{l}\text { Metal } \\
{[14,67,112-124]}\end{array}$ & $\begin{array}{l}\text { National Institute of Standards and Technology: 500, C1123, C1252, C1257 } \\
\text { (copper); 685, 8053, 8054, 8059, 8062, 8063, 8065, 8068, 8074, } 8077 \text { (gold); } 481 \\
\text { (gold-silver alloy); 610, 612 } \\
\text { Federal Institute for Materials Research and Testing: } 211,227,228,378 \text { (bronzes) } \\
\text { Centre de Developpement des Industries de Mise en Forme des Materiaux: B10, } \\
\text { B12 (bronzes) } \\
\text { Bureau of Analysed Samples: 50.03-4, 50.04-4, 51.13-4, 71.32-4 (bronzes) } \\
\text { MBH Analytical: 32X SN1, 32X SN2, 32X SN3 (bronzes); 31X TB2, 31X TB4 } \\
\text { (brasses) } \\
\text { Swerea Nordic CRM Working Group: JK 27A (stainless steel), JK 2D (pure iron) } \\
\text { U.S. Geological Survey: GSE-1G (lead isotope ratio) }\end{array}$ \\
\hline $\begin{array}{l}\text { Human fossil } \\
{[125-128]}\end{array}$ & $\begin{array}{l}\text { National Institute of Standards and Technology: } 987 \text { (strontium isotope ratio); } \\
610,612 \\
\text { New York State Department of Health: RM05-1, RM05-2, RM05-4 (lead-dosed } \\
\text { caprine bone pellets) } \\
\text { China National Analysis Center: GBW0760 (human hair) }\end{array}$ \\
\hline $\begin{array}{l}\text { Mortar } \\
{[129-133]}\end{array}$ & $\begin{array}{l}\text { National Institute of Standards and Technology: 1d (argillaceous limestone); 610, } \\
611,612,613 \\
\text { U.S. Geological Survey: BCR-2G }\end{array}$ \\
\hline
\end{tabular}

Imaging techniques allow for clear mapping of a distribution of selected elements in forms of $2 \mathrm{D}[53,90,147,174]$ or $3 \mathrm{D}[180]$ models. Van Elteren with co-workers [180] applied a 3D LA-ICP-MS mapping procedure to the analysis of historic glass to study degradation mechanisms of glass weathering. Previous analytical protocols required 
cross-sectional fragments of glass for the analysis, which was omitted in this project. LA-ICP-MS measurements are relatively fast; therefore, many analyses were repeated in a reasonable period of time.

Statements indicating a low degree of changes due to LA-ICP-MS analysis include such wording as quasi-destruction-free [113], virtually non-destructive [19, 32, 54, $76,93]$ or relatively/almost non-destructive $[12,29,144-146]$. Other papers [35, 77, 125, 147-150] state that LA-ICP-MS as a micro-destructive method provides multielemental information with minimal sample damage and should rather be understood as an attempt to present the method in the best light, not as a precise term describing effects of ablation.

Possible controversies with assigning attributes of destructiveness or invasiveness to any analytical protocol have been considered in works of Wouters [3, 151], who suggested to use the term intervention instead. The degree of intervention might be described at three levels: (i) molecular (low change), (ii) microscopic (medium change) and (iii) visual (high change). Wouters nomenclature is rational and useful to clarify the scale of changes provoked by application of instrumental methods to the measurements of cultural heritage objects.

According to Wouters [3, 151], microscopic interventions/medium changes to cultural heritage objects can be expected if the ablation was executed directly from the analyzed item. Ablation is usually performed inside ablation cells; therefore, a size of an object to be analyzed is important $[7,53$, 54, 152-157]. Variable constructions of ablation cells were described in the literature, allowing the best selection of analytical approach for particular size and shape of objects.

\section{Degree of intervention induced by LA-ICP-MS measurements}

The development of methodology for studying cultural heritage objects is paired with specific restrictions in order to keep the analyzed objects possibly intact, to remain them within the molecular or microscopic degrees of intervention. These requirements can be met during the application of LA-ICP-MS; however, depending on the size and uniqueness of investigated objects, different scenarios for conducting laser ablation can be proposed (Fig. 3).

\section{CULTURAL HERITAGE OBJECTS}

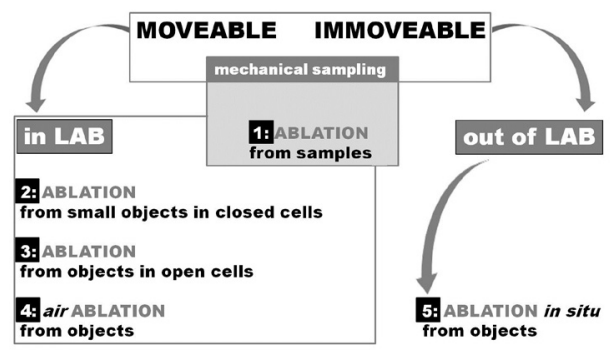

Fig. 3. Various scenarios for using LA-ICP-MS during investigations (the description is given in the text).

\subsection{Scenario 1: mechanical sampling followed by laser ablation from the taken fragments}

The most common scenario of using LA-ICP-MS for the analysis of cultural heritage objects concerns ablation of samples mechanically taken from artifacts (Fig. 4). Mechanical sampling enables the investigations of the chemical composition of immoveable or large moveable objects which cannot be transported to a laboratory. The step of mechanical sampling takes responsibility of the scale of intervention to the object of interest because the same sam- 

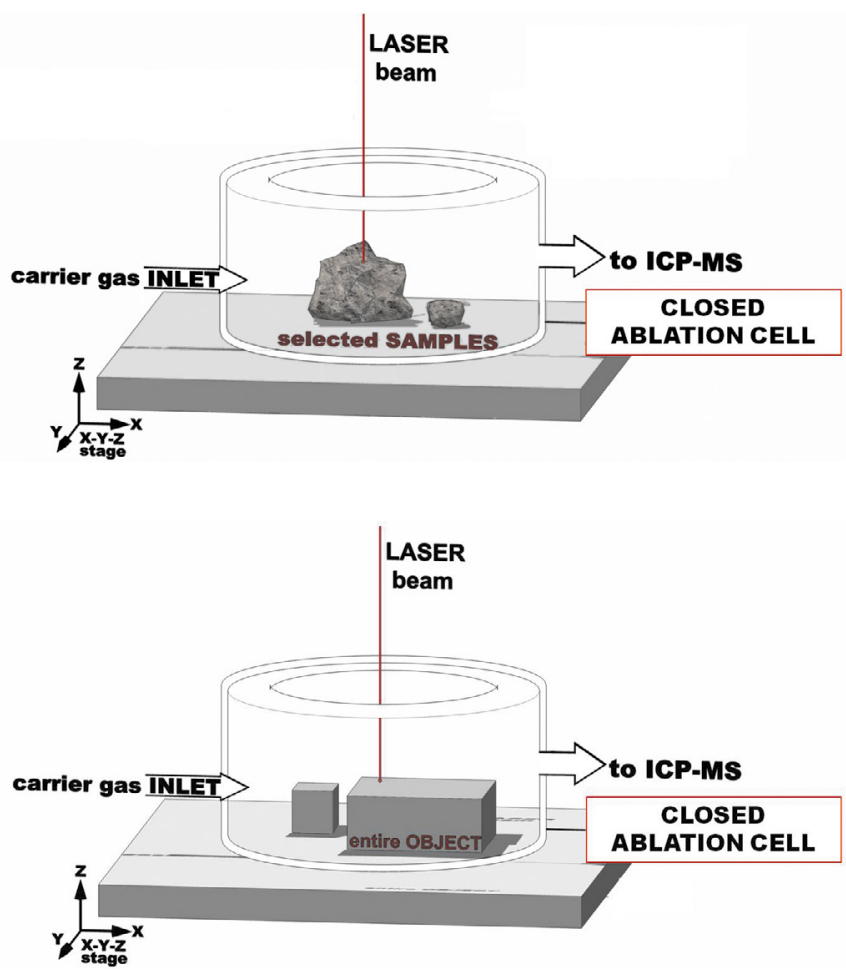

Fig. 4. Scenario 1: ablation executed in closed cell from samples.

Fig. 5. Scenario 2: ablation executed directly from the object, which fits to a closed ablation cell. pling, not the process of laser ablation, is the most destructive step in the whole analytical procedure.

Collected fragments can be additionally analyzed by other methods [74, 96, 101, $102,105,115,126,129,135,158-165]$ to broaden the knowledge about their chemical composition. Small samples are often taken from historical glass to be analyzed by means of SEM-EDX and LA-ICP-MS [38, 74, 79, $84-89,135,166-169]$. In this case, small fragments are embedded in resin blocks and prepared in accordance to EDX analysis requirements (polishing, carbon coating). They can be analyzed in the same form by means of both methods. The results from SEM-EDX analysis may be used first to select and then to determine the content of the internal standard $\left(\mathrm{CaO}\right.$ or $\left.\mathrm{SiO}_{2}\right)$. These two methods provide results with a satisfactory correlation for major and minor elements, while LA-ICP-MS additionally allows for determination of trace elements.

The incorporation of LA-ICP-MS into research involves the necessity to sample large objects. The inner volume of the standard closed cell prerequisites the size of an item which can fit it during ablation; therefore, objects of small sizes can be located inside a cell, allowing direct laser ablation from the object (Fig. 5).

\subsection{Scenario 2: direct laser ablation from small objects}

The size of an item plays an important role in the analytical procedure including LA-ICP-MS investigations when no agreement can be obtained for the mechanical sampling of the object. The commercially 
available ablation cells are characterized by the defined dimensions and only objects that are small enough to be placed inside the ablation cells can be ablated directly $[11,12$, $78,93,106,117,127,170-173]$. This scenario allows not only to lower the level of intervention to the minimum, but also the most time-consuming step of samples preparation is eliminated and LA-ICP-MS measurements can be performed much faster $[18,19]$.

The shortening of the analysis time is a beneficial side-effect of the scenario 2 and is helpful for investigations of objects which are found in large quantities, like glass beads from archaeological sites all around the world [76]. Robertshaw et al. [18] analyzed more than 360 glass beads from the southern Africa, while Dussubieux et al. [19] reported the results for 486 items of archaeological glass beads from India, Sri Lanka, Bangladesh, Thailand, Malaysia, Indonesia, Cambodia, Vietnam and Turkey. Thanks to availability to a number of data on a large group of similar objects, it was possible to conduct statistical surveys and extract information about the existence of variable sub-groups representing several glass-making centers. The hypothesis about the existence of a few glass making centers in different locations was supported by the results of LA-ICP-MS investigations of mineral soda-alumina glass and allowed to distinguish the sub-groups on the basis of concentrations of selected elements (Ca, $\mathrm{Mg}$, $\mathrm{U}, \mathrm{Ba}, \mathrm{Sr}, \mathrm{Zr}$ and $\mathrm{Cs})$.

\subsection{Scenario 3: the use of open ablation cells}

Objects that are too large to be placed inside the ablation cell can be analyzed with the use of so called "open" or "moveable" ablation cells (Fig. 6) [53, 54, 152-153, 174]. Small open ablation cells are adhered to the surface of an object, maintaining the degree of inter- vention of LA-ICP-MS measurements at the microscopic level $[53,54,175]$.

The use of open ablation cells allows to avoid mechanical sampling from valuable objects and thus expands the range of applications of LA-ICP-MS. The use of such scenario is more time-consuming than the previously described ones. The object has to be handled with the highest caution to avoid damage caused by mounting at the $\mathrm{x}-\mathrm{y}-\mathrm{z}$ stage for the time of ablation. Open cells are usually characterized by small intrinsic volumes that permit the shortening of the wash-out-time from the cell; therefore, the investigations of elemental distribution with the use of this scenario are facilitated. Various designs of open cells were proposed [53, 54, 152, 153, 175, 176]; however, the optimum construction should allow their use irrespective of the particular size or shape of the object and would be insensitive to the surface irregularity.

Devos, Moor and Lienemann [54] described the successful use of ablation open cell during elemental analysis of silver artifacts. The open cell was used because the objects of interest were too large to fit into a standard ablation cell and the mechanical sampling of them was not allowed. Contents of $\mathrm{Ag}, \mathrm{Zn}, \mathrm{Cd}, \mathrm{Sn}, \mathrm{Sb}, \mathrm{Au}, \mathrm{Pb}$ and $\mathrm{Bi}$ were determined and allowed to discriminate one forgery among the originals. A crater-to-crater repeatability of the normalized signals was reported below $10 \% \operatorname{RSD}(n=3)$ for most of the selected elements with detection limits within the sub-ppm to ppm range.

Low limits of detection are the most preferred advantages of LA-ICP-MS measurements. Recently, sampling systems with no ablation cell have been developed for a direct atmospheric ablation $[67,177]$, according to the scenario 4 (Fig. 7), and also allow to maintain limits of detection at the 


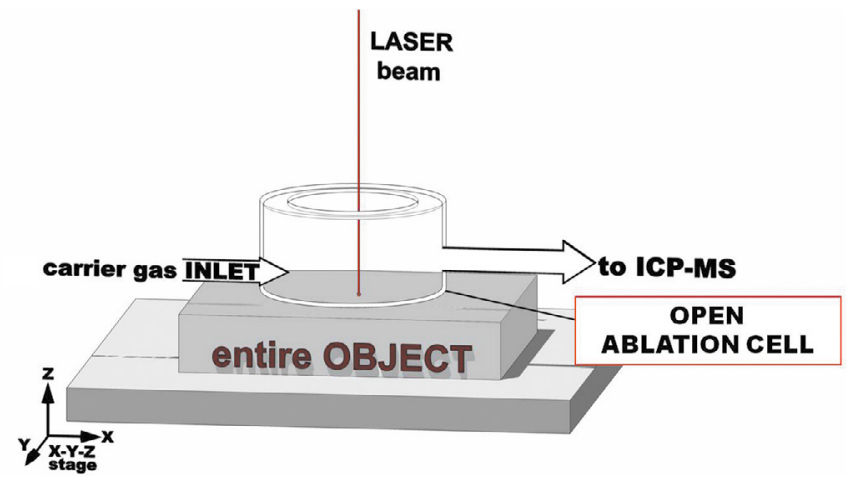

Fig. 6. Scenario 3: ablation executed in an open cell attached to a surface of an object.

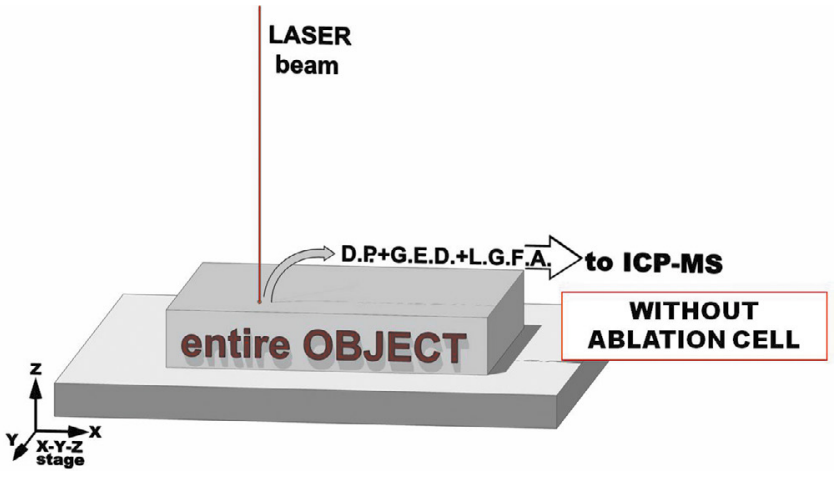

Fig. 7. Scenario 4: air ablation without using any ablation cell. D.P. $=$ diaphragm pump; G.E.D. = gas exchange device; L.G.F.A. $=$ laminar gas flow adapter [177]. low level for most of the elements. This kind of technical solution seems very promising for all cultural heritage objects investigations in the near future, releasing the LA-ICP-MS measurements from having to be run only in a sealed ablation cell.

\subsection{Scenario 4: direct laser ablation from cultural heritage objects in ambient air}

The innovative direct sampling by laser ablation in ambient air during LA-ICP-MS measurements was described by Kovacs et al. [67] in 2010. The open set-up was used for ablation with no cell at all. The exchange of air to argon by means of a gas exchange device was required together with a diaphragm pump, which then permitted the transpor- tation of the laser-generated aerosol into the ICP-MS. The level of oxides formation was monitored carefully as it was considered a possible limitation of this method. Oxide formation and count rates of the gas blank or potential spectral interferences from polyatomic ions were satisfactory and the accuracy of the obtained results was similar to the one achieved with closed transport systems.

In 2013 Dorta et al. [178] described laser ablation sampling in air under atmospheric pressure coupled with MC-ICP-MS. A lead isotope ratio analysis was performed, using two brass certified reference materials, galena and zircon. The precision and accuracy of the measurements were similar to the obtained by conventional LA-MC-ICP-MS in a sealed cell and helium atmosphere. The direction of 
development of such systems enabling the ablation in ambient air directly from the surface of unique objects seems very promising. Such instrumentation would cancel most of limitations for dimensions of objects easily analyzed by means of LA-ICP-MS. There is still a need to transport objects to the laboratory; therefore, the simplicity of using LA-ICP-MS method will remain mostly for moveable objects.

\subsection{Scenario 5: use of portable laser ablation sampling device}

The use of a portable laser sampling device facilitates the analysis of any immoveable cultural heritage objects (Fig. 8). These objects were the last category, which could not be investigated by means of LA-ICP-MS without mechanical sampling until the paper transported to a laboratory. The portable LA sampling device has already been successfully applied to the elemental analysis of ancient Chinese ceramics [177] and the determination of lead isotopic composition [196]. Taking into account all demands of the conservation science or archaeometric investigations, the possible use of the portable LA set up has a huge potential to be used in the future analysis of all cultural heritage objects, which cannot be examined by any other technique without invasive sampling.

The portable laser ablation sampling utilizes all advantages of microscopic degree of intervention caused by laser ablation. Some essential problems, such as polyatomic interferences caused by filter material during the subsequent re-ablation in the lab, element-dependent sensitivity enhancement, signal fluctuations and elemental fractiona-

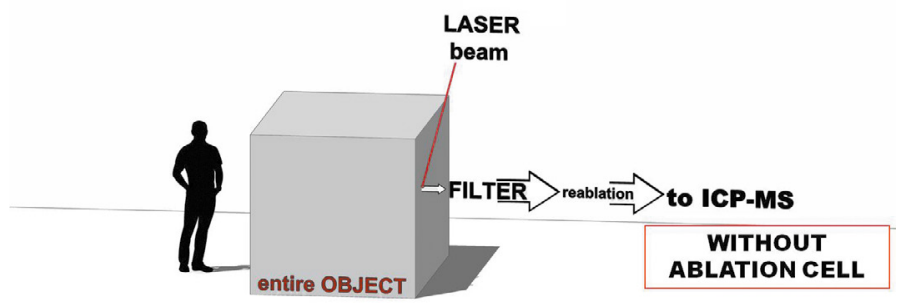

Fig. 8. Scenario 5: air ablation with collection of particulate matter on filters and subsequent re-ablation inside a closed cell. by Glaus et al. [177] reported the use of the portable sampling device applicable to the ablation of any object regardless of its size and location. Ablated particles are collected on special filters. Filters protected from contamination are transported to a laboratory, where they can be examined either by means of LA-ICP-MS with re-ablation or by any other instrumental method.

This approach allows the in situ microsampling of all objects (apart from the underwater cultural heritage) in spite of their dimensions and possibility for being tion have been observed [177]; however, these limitations do not diminish the attractiveness of the proposed method for the elemental and isotopic analysis of immoveable cultural heritage objects.

\section{Multi-technique approach incorporating LA-ICP-MS}

The results of sensitive LA-ICP-MS elemental/isotopic measurements can be used to support the use of other instrumental meth- 
ods such as Scanning Electron Microscopy with Energy Dispersive X-Ray Spectrometry (SEM-EDS) $[12,31,38,74,79,112,118,130$, 135, 166, 170, 181, 182], Electron Probe Microanalysis (EPMA) [75, 80, 81, 97, 112, 167, 183-185], X-Ray Fluorescence (XRF) $[16,31,35,44,93,94,98,119,120]$, Proton Induced X-Ray Emission [22, 41, 95, 114, 186, 187] or Neutron Activation Analysis (NAA) $[23,36,99,100,107,108,114,146$, 188-192]. Leroy et al. [193] reported the first application of confocal Synchrotron Radiation micro X-Ray Fluorescence (SR-mXRF) with LA-ICP-MS. They examined microscopic slag inclusions in mediaeval armours attributed to a Lombard provenance from stylistic considerations. The potential of coupling SR-m-XRF with LA-ICP-MS during quantification of trace elements in slag inclusions was evaluated with respect to drawbacks and advantages of each method.

LA-ICP-MS was merged with instrumental methods providing molecular information about the determined compounds: Raman spectroscopy (RS) [79, 121, 168, 194], Fourier Transformed Infrared Spectroscopy (FTIR) [131, 194, 195] or Gas Chromatography Mass Spectrometry (GC/MS) [195] during glass, ceramic, bones and wall-paintings investigations.

Di Bella et al. [82], Gallo et al. [83], Walton et al. [169] described the application of X-ray Powder Diffraction (XRPD) together with LA-ICP-MS for the historic glass analysis. The combination of Computed Tomography (CT) and LA-ICP-MS was reported by A. Kreiter et al. [109]. The authors used CT to assess differences in the porosity, number and size of inclusions in three visible distinguishable layers of a ceramic figurine. The LA-ICP-MS analysis was carried out to quantify major, minor and trace elements in the abovementioned figurine layers. The application of these complementary methods led to the answer to a question whether the analyzed object was formed over time using material from the same resource.

\section{Conclusions}

The interest in the use of laser ablation ICP-MS in archaeometry and restoration/ conservation science is constantly increasing; however, the non-destructive character of the measurements pointed out by Lahanier [2] as one of the requirements for instrumental methods most suitable for the analysis of cultural heritage objects cannot be fully attributed to LA-ICP-MS.

The possibility to investigate cultural heritage objects by means of LA-ICP-MS should be always verified according to conservators recommendations, taking into account dimensions of the analyzed objects and the possibility of samples collections, their number and size. The mechanical sampling is one of the suggested solutions, while the other is the possibility to perform the direct laser ablation from cultural heritage objects. The use of open ablation cells or direct air ablation was proposed when the mechanical sampling is impossible or unacceptable. Such direct ablation offers many advantages and expands the usefulness of LA-ICP-MS for the analysis of cultural heritage objects. The real milestone of the development of LA-ICP-MS was the use of mobile LA systems allowing for microsampling independently from a size and the mobility of the analyzed object.

\section{Acknowledgements}

This work was a part of the broader research project funded by the National Science Center of Poland, No 2011/01/B/ST4/00478. It was partially realized 
at the Biological and Chemical Research Centre, University of Warsaw, established within the project co-financed by European Union from the European Regional Development Fund under the Operational Program Innovative Economy, 2007-2013.

\section{References}

[1] R. Van Grieken, K. Janssens, Non-destructive testing and microanalysis for the diagnostics and conservation of cultural heritage, Taylor \& Francis/ Balkema Publishers, Rotterdam 2005.

[2] C. Lahanier, "Scientific methods applied to the study of ART objects", Mikrochimica Acta, 2 (1991) 245-254, DOI: 10.1007/BF01245512.

[3] J. Wouters, "Surrealism in science: the difference between analysis and analysis" in: J.J. Boon, E.S.B. Ferreira (Eds.), Reporting Highlights of the De Mayerne Programme, The Hague, 2006, pp. 13-20.

[4] M. Resano, E. Garcia-Ruiz, F. Vanhaecke, "Laser ablation-inductively coupled plasma mass spectrometry in archaeometric research", Mass Spectrometry Review, 29 (2010) 55-78 - DOI: 10.1002/mas.20220.

[5] B. Giussani, D. Monticelli, L. Rampazzi, "Role of laser ablation-inductively coupled plasma-mass spectrometry in cultural heritage research: A review", Analytica Chimica Acta, 635 (2009) 6-21, DOI: 10.1016/j.aca.2008.12.040.

[6] G. Spoto, G. Grasso, "Spatially resolved mass spectrometry in the study of art and archaeological objects", Trac-Trends in Analytical Chemistry, 30 (2011) 856-863, DOI: 10.1016/j.trac.2011.01.016.

[7] C. C. Garcia, H. Lindner, K. Niemax, "Laser ablation inductively coupled plasma mass spectrometry-current shortcomings, practical suggestions for improving performance, and experiments to guide future development", Journal of Analytical Atomic Spectrometry, 24 (2009) 14-26, DOI: 10.1039/ B813124B.

[8] J. Koch, D. Guenther, "Review of the State-of-theArt of Laser Ablation Inductively Coupled Plasma Mass Spectrometry", Applied Spectroscopy, 65 (2011) 155-162, DOI: 10.1366/11-06255.

[9] S. A. Junk, "Ancient artefacts and modern analytical techniques - Usefulness of laser ablation
ICP-MS demonstrated with ancient gold coins", Nuclear Instruments \& Methods in Physics Research Section B, 181 (2001) 723-727, DOI: 10.1016/S0168583X(01)00366-4.

[10] R. E. Russo, X. Mao, J. J. Gonzalez, V. Zorba, J. Yoo, "Laser Ablation in Analytical Chemistry", Analytical Chemistry, 85 (2013) 6162-6177, DOI: 10.1021/ac4005327.

[11] G. H. Fontaine, K. Hametner, A. Peretti, D. Guenther, "Authenticity and provenance studies of copper-bearing andesines using $\mathrm{Cu}$ isotope ratios and element analysis by fs-LA-MC-ICPMS and ns-LAICPMS", Analytical and Bioanalytical Chemistry, 398 (2010) 2915-2928, DOI: 10.1007/s00216-010-4245-z.

[12] D. Barca, G. Lucarin, F. G. Fedele, "The provenance of obsidian artefacts from the WĀDI ATH-THAYYILAH 3 Neolithic side (eastern Yemen Plateau) by LA-ICP-MS", Archaeometry, 54 (2012) 603-622, DOI: 10.1111/j.1475-4754.2011.00643.x.

[13] C. M. Jackson, P. T. Nicholson, "The provenance of some glass ingots from the Uluburun shipwreck", Journal of Archeological Science, 37 (2010) 295-301, DOI: 10.1016/j.jas.2009.09.040.

[14] R. Kovacs, S. Schlosser, S. P. Staub, A. Schmiderer, E. Pernicka, D. Guenther, "Characterization of calibration materials for trace element analysis and fingerprint studies of gold using LA-ICP-MS", Journal of Analytical Atomic Spectrometry, 24 (2009) 476-483, DOI: 10.1039/B819685K.

[15] A.-M. Desaulty, P. Dillmann, M. L'Heritiera, C. Mariet, B. Gratuze, J. L. Joron, P. Fluzin, "Does it come from the Pays de Bray? Examination of an origin hypothesis for the ferrous reinforcements used in French medieval churches using major and trace element analyses", Journal of Archeological Science, 36 (2009) 2445-2462, DOI: 10.1016/j.jas.2009.07.002.

[16] L. B. Brostoff, J. J. Gonzalez, P. Jett, R. E. Russo, "Trace element fingerprinting of ancient Chinese gold with femtosecond laser ablation-inductively coupled mass spectrometry", Journal of Archeological Science, 36 (2009) 461-466, DOI: 10.1016/j. jas.2008.09.037.

[17] I. Scharlotta, "Micro-sampling of human bones for mobility studies: diagenetic impacts and potentials for elemental and isotopic research", Journal of 
Archeological Science, 37 (2010) 1929-1941, DOI: 10.1016/j.jas.2013.07.014.

[18] P. Robertshaw, M. Wood, E. Melchiorre, R. S. Popelka-Filcoff, M. D. Glascock, "Southern African glass beads: chemistry, glass sources and patterns of trade", Journal of Archeological Science, 37 (2010) 1898-1912, DOI: 10.1016/j.jas.2010.02.016.

[19] L. Dussubieux, B. Gratuze, M. Blet-Lemarquand, "Mineral soda alumina glass: occurence and meaning", Journal of Archeological Science, 37 (2010) 1646-1655, DOI: 10.1016/j.jas.2010.01.025.

[20] P. Robertshaw, N. Benco, M. Wood, L. Dussubieux, E. Melchiorre, A. Ettahiri, "Chemical analysis of glass beads from medieval AL-BASRA (Morocco)", Archaeometry, 52 (2010) 355-379 DOI: 10.1111/j.1475-4754.2009.00482.x.

[21] S. M. Fitzpatrick, H. Takamiya, H. Neff, W. R. Dickinson, "Compositional analysis of Yayoi-Heian period ceramics from Okinawa: Examining the potential for provenance study", Geoarchaeology-an International Journal, 21 (2006) 803-822 - DOI: 10.1002/gea.20140.

[22] Z. Smit, K. Janssens, E. Bulska, B. Wagner, M. Kos, I. Lazar, "Trace element fingerprinting of facon-de-Venise glass", Nuclear Instruments \& Methods in Physics Research Section B, 239 (2005) 94-99, DOI: 10.1016/j.nimb.2005.06.182.

[23] J. H. Sterba, F. Munnik, N. J. G. Pearce, "Raising the temper-mu-spot analysis of temper inclusions in experimental ceramics", Journal of Radioanalytical and Nuclear Chemistry, 291 (2012) 25-35, DOI: 10.1007/s10967-011-1208-6.

[24] I. De Raedt, K. Janssens, J. Veeckman, L. Vincze, B. Vekemans, T. E. Jeffries, "Trace analysis for distinguishing between Venetian and facon-de-Venise glass vessels of the $16^{\text {th }}$ and $17^{\text {th }}$ century", Journal of Analytical Atomic Spectrometry, 16 (2001) 1012-1017, DOI: 10.1039/b102597j.

[25] T. Zhu, W. Sun, H. Zhang, H. Wang, G. Kuang, L. Lv, "Study on the provenance of Xixun Qingbai wares from the Northern Song Dynastyof China", Archaeometry, 54 (2012) 475-488 - DOI: 10.1111/j.1475-4754.2011.00636.x.

[26] A. Shortland, N. Rogers, K. Eremin, “Trace element discriminants between Egyptian and
Mesopotamian Late Bronze Age glasses", Journal of Archeological Science, 34 (2007) 781-789 - DOI: 10.1016/j.jas.2006.08.004.

[27] M. F. Guerra, C. O. Sarthre, A. Gondonneau, J. N. Barrandon, "Precious metals and provenance enquiries using LA-ICP-MS", Journal of Archeological Science, 26 (1999) 1101-1110 - DOI: 10.1006/ jasc.1999.0405.

[28] L. M. Mallory-Greenough, J. D. Greenough, G. Dobosi, J. V. Owen, "Fingerprinting ancient Egyptian quarries: Preliminary results using laser ablation microprobe-inductively coupled plasma-mass spectrometry", Archaeometry, 41 (1999) 227-238, DOI: 10.1111/j.1475-4754.1999.tb00979.x.

[29] S. L. Eckert, W. D. James, "Investigating the production and distribution of plain ware pottery in the Samoan archipelago with laser ablation-inductively coupled plasma-mass spectrometry (LA-ICP-MS)", Journal of Archeological Science, 38 (2011) 2155-2170, DOI: 10.1016/j.jas.2011.03.009.

[30] N. Sharratt, M. Golitko, P. R. Williams, L. Dussubieux, "Ceramic Production During the Middle Horizon: Wari and Tiwanaku Clay Procurement in the Moquegua Valley, Peru", Geoarchaeology-an International Journal, 24 (2009) 792-820, DOI: 10.1002/gea.20288.

[31] D. Miriello, D. Barca, A. Bloise, A. Ciarallo, G. M. Crisci, T. De Rose, C. Gattuso, F. Gazineo, M. F. La Russa, "Characterisation of archaeological mortars from Pompeii (Campania, Italy) and identification of construction phases by compositional data analysis", Journal of Archeological Science, 37 (2010) 2207-2223, DOI: 10.1016/j.jas.2010.03.019.

[32] R. J. Speakman, H. Neff, "Evaluation of painted pottery from the Mesa Verde region using laser ablation-inductively coupled plasma-mass spectrometry (LA-ICP-MS)", American Antiquity, 67 (2002)137-144, DOI: 10.2307/2694882.

[33] M. E. Beck, H. Neff, "Hohokam and Patayan interaction in southwestern Arizona: Evidence from ceramic compositional analyses", Journal of Archeological Science, 34 (2007) 289-300, DOI: 10.1016/j. jas.2006.05.003.

[34] L. Rampazzi, B. Rizzo, C. Colombo, C. Conti, M. Realini, U. Bartolucci, M. P. Colombini, A. Spiriti, 
L. Facchin, "The stucco decorations from St. Lorenzo in Laino (Como, Italy): The materials and the techniques employed by the "Magistri Comacini", Analytica Chimica Acta, 630 (2008) 91-100, DOI: 10.1016/j.aca.2008.09.052.

[35] J. Perez-Arantegui, M. Resano, E. Garcia-Ruiz, F. Vanhaecke, C. Roldan, J. Ferrero, J. Coll, “Characterization of cobalt pigments found in traditional Valencian ceramics by means of laser ablation-inductively coupled plasma mass spectrometry and portable X-ray fluorescence spectrometry", Talanta, 74 (2008) 1271-1280, DOI: 10.1016/j.talanta.2007.08.044.

[36] D. V. Hill, R. J. Speakman, M. D. Glascock, "Chemical and mineralogical characterization of Sasanian and Early Islamic glazed ceramics from the Deh Luran Plain, southwestern Iran", Archaeometry, 46 (2004) 585-605, DOI: 10.1111/j.14754754.2004.00175.x.

[37] M. Senn, U. Gfeller, B. Guenette-Beck, P. Lienemann, A. Ulrich, "Tools to qualify experiments with bloomery furnaces", Archaeometry, 52 (2010) 131-145 - DOI: 10.1111/j.1475-4754.2009.00461.x.

[38] S. Cagno, M. Mendera, T. Jeffries, K. Janssens, "Raw materials for medieval to post-medieval Tuscan glassmaking: new insight from LA-ICP-MS analyses", Journal of Archaeological Science, 37 (2010) 3030-3036, DOI: 10.1016/j.jas.2010.06.030.

[39] I. Caterina, T. Maurizio, S. Giuseppe, "Archaeometallurgy in Messina: iron slag from a dig at block p, laboratory analyses and interpretation", Mediterranean Archaeology \& Archaeometry, 8 (2008) 49-60.

[40] S. Duwe, H. Neff, “Glaze and slip pigment analyses of Pueblo IV period ceramics from east-central Arizona using time of flight-laser ablation-inductively coupled plasma-mass spectrometry (TOFLA-ICP-MS)", Journal of Archaeological Science, 34 (2007) 403-414, DOI: 10.1016/j.jas.2006.06.001.

[41] Z. Smit, P. Pelicon, G. Vidmar, B. Zorko, M. Budnar, G. Demortier, B. Gratuze, S. Sturm, M. Necemer, P. Kump, M. Kos, "Analysis of medieval glass by X-ray spectrometric methods", Nuclear Instruments \& Methods in Physics Research Section B, 161 (2000) 718-723, DOI: 10.1016/S0168-583X(99)00947-7.

[42] M. P. Coustures, D. Beziat, F. Tollon, C. Domergue, L. Long, A. Rebiscoul, “The use of trace element analysis of entrapped slag inclusions to establish ore - bar iron links: examples from two Gallo-Roman iron-making sites in France (Les Martys, Montagne Noire, and Les Ferrys, Loiret)", Archaeometry, 45 (2003) 599-613, DOI: 10.1046/j.14754754.2003.00131.x.

[43] B. Wagner, E. Bulska, W. Sobucki, "Magnesium distribution in paper subjected to deacidification investigated by means of Laser Ablation Inductively Coupled Plasma Mass Spectroscopy" Journal of Cultural Heritage, 9 (2008) 60-65, DOI: 10.1016/j. culher.2007.11.001.

[44] J. Malesic, M. Kojc, V. S. Selih, "Assessment of the effect of various bleaching agents on papers with foxing stains", Restaurator-International Journal for the Preservation of Library and Archival Material, 29 (2008) 142-154, DOI: 10.1515/rest.2008.010.

[45] B. Wagner, E. Bulska, A. Drewniak, W. Sobucki, D. Rams, "LA-ICPMS investigations of a long-term effect of indoor air pollution on paper", Analytical Chemistry (Warsaw), 54 (2009) 1253-1264.

[46] B. Wagner, E. Bulska, "On the use of laser ablation inductively coupled plasma mass spectrometry for the investigation of the written heritage", Journal of Analytical Atomic Spectrometry, 19 (2004) 1325-1329, DOI: 10.1039/B408384A.

[47] A. L. Gray, "Solid sample introduction Laser ablation for inductively coupled plasma source mass spectrometry", Analyst, 110 (1985) 551-556.

[48] M. Thompson, J. E. Goulter, F. Sieper, "Laser ablation for the introduction of solid samples into an inductively coupled plasma for atomic emission spectrometry", Analyst, 106 (1981) 32-39.

[49] J. W. Carr, G. Horlick, "Laser vaporization of solid metal samples into an inductively coupled plasma”, Spectrochimica Acta Part B, 37 (1982) 1-15, DOI: 10.1016/0584-8547(82)80003-7.

[50] D. Gunther, S. E. Jackson, H. P. Longerich, "Laser ablation and arc/spark solid sample introduction into inductively coupled plasma mass spectrometers", Spectrochimica Acta Part B, 54 (1999) 381-409, DOI: 10.1016/S0584-8547(99)00011-7.

[51] R. Kovacs, K. Nishiguchi, K. Utani, D. Guenther, "Development of direct atmospheric sampling for laser ablation-inductively coupled plasma-mass spec- 
trometry", Journal of Analytical Atomic Spectrometry, 25 (2010) 142-147, DOI: 10.1039/B924425E.

[52] D. Gunther, B. Hattendorf, "Solid sample analysis using laser ablation inductively coupled plasma mass spectrometry", Trac-Trends in Analytical Chemistry, 24 (2005) 255-265, DOI: 10.1016/j. trac.2004.11.017.

[53] B. Wagner, W. Jedral, "Open ablation cell for LA-ICP-MS investigations of historic objects", Journal of Analytical Atomic Spectrometry, 26 (2011) 2058-2063, DOI: 10.1039/C1JA10137D.

[54] W. Devos, C. Moor, P. Lienemann, "Determination of impurities in antique silver objects for authentication by laser ablation inductively coupled plasma mass spectrometry (LA-ICP-MS)", Journal of Analytical Atomic Spectrometry, 14 (1999) 621-626, DOI: 10.1039/A900073I.

[55] S. M. Eggins, L. P. J. Kinsley, J. M. G. Shelley, "Deposition and element fractionation processes during atmospheric pressure laser sampling for analysis by ICP-MS", Applied Surface Science, 127 (1998) 278-286, DOI: 10.1016/S0169-4332(97)00643-0.

[56] P. M. Outridge, W. Doherty, D. C. Gregoire, "The formation of trace element-enriched particulates during laser ablation of refractory materials", Spectrochimica Acta Part B, 51 (1996) 1451-1462, DOI: 10.1016/0584-8547(96)01542-X.

[57] P. M. Outridge, W. Doherty, D. C. Gregoire, "Ablative and transport fractionation of trace elements during laser sampling of glass and copper", Spectrochimica Acta Part B, 52 (1997) 2093-2102, DOI: 10.1016/S0584-8547(97)00112-2.

[58] B. J. Fryer, S. E. Jackson, H. P. Longerich, "The design, operation and role of the laser-ablation microprobe coupled with an inductively coupled plasma; mass spectrometer (LAM-ICP-MS) in the earth sciences", The Canadian Mineralogist, 33 (1995) 303-312.

[59] J. Gonzalez, X. L. Mao, J. Roy, S. S. Mao, R. E. Russo, "Comparison of 193, 213 and $266 \mathrm{~nm}$ laser ablation ICP-MS", Journal of Analytical Atomic Spectrometry, 17 (2002) 1108-1113, DOI: 10.1039/ B202122F.

[60] I. Horn, D. Gunther, “The influence of ablation carrier gasses $\mathrm{Ar}, \mathrm{He}$ and $\mathrm{Ne}$ on the particle size distribution and transport efficiencies of laser ablation-induced aerosols: implications for LA-ICP-MS", Applied Surface Science, 207 (2003) 144-157, DOI: 10.1016/S0169-4332(02)01324-7.

[61] R. E. Russo, X. L. Mao, H. C. Liu, J. Gonzalez, S. S. Mao, "Laser ablation in analytical chemistry a review”, Talanta, 57 (2002) 425-451, DOI: 10.1016/ S0039-9140(02)00053-X.

[62] T. E. Jeffries, N. J. G. Pearce, W. T. Perkins, A. Raith, "Chemical fractionation during infrared and ultraviolet laser ablation inductively coupled plasma mass spectrometry-implications for mineral microanalysis", Analytical Communications, 33 (1996) 35-39, DOI: 10.1039/AC9963300035.

[63] H. Wiltsche, D. Guenther, "Capabilities of femtosecond laser ablation ICP-MS for the major, minor, and trace element analysis of high alloyed steels and super alloys", Analytical and Bioanalytical Chemistry, 399 (2011) 2167-2174, DOI: 10.1007/ s00216-010-4605-8.

[64] R. Glaus, R. Kaegi, F. Krumeich, D. Guenther, "Phenomenological studies on structure and elemental composition of nanosecond and femtosecond laser-generated aerosols with implications on laser ablation inductively coupled plasma mass spectrometry", Spectrochimica Acta Part B, 65 (2010) 812-822, DOI: 10.1016/j.sab.2010.07.005.

[65] M. Waelle, J. Koch, D. Tabersky, K. Hametner, N. D. Zhigadlo, S. Katrych, J. Karpinski, D. Guenther, "Analyses of lithium-doped and pure magnesium diboride using ultraviolet nano- and femtosecond laser ablation inductively coupled plasma mass spectrometry", Journal of Analytical Atomic Spectrometry, 25 (2010) 193-195, DOI: 10.1039/B914547H.

[66] J. Koch, A. von Bohlen, R. Hergenroder, K. Niemax, "Particle size distributions and compositions of aerosols produced by near-IR femto- and nanosecond laser ablation of brass", Journal of Analytical Atomic Spectrometry, 19 (2004) 267-272, DOI: 10.1039/B310512A.

[67] R. Kovacs, K. Nishiguchi, K. Utani, D. Guenther, "Development of direct atmospheric sampling for laser ablation-inductively coupled plasma-mass spectrometry", Journal of Analytical Atomic Spectrometry, 25 (2010) 142-147, DOI: 10.1039/B924425E. 
[68] D. Gunther, H. Cousin, B. Magyar, I. Leopold, "Calibration Studies on Dried Aerosols for Laser Ablation-Inductively Coupled Plasma Mass Spectrometry", Journal of Analytical Atomic Spectrometry, 12 (1997)165-170, DOI: 10.1039/A604531F.

[69] J. J. Leach, L. A. Allen, D. B. Aeschliman, R. S. Houk, " $\mathrm{C}$ alibration of Laser Ablation Inductively Coupled Plasma Mass Spectrometry Using Standard Additions with Dried Solution Aerosols", Analytical Chemistry, 71 (1999) 440-445, DOI: 10.1021/ac980855i.

[70] L. Halicz, D. Gunther, "Quantitative analysis of silicates using LA-ICP-MS with liquid calibration", Journal of Analytical Atomic Spectrometry, 19 (2004) 1539-1545, DOI: 10.1039/B410132D.

[71] D. Gunther, R. Frischknecht, H. J. Muschenborn, C. A. Heinrich, "Direct liquid ablation: a new calibration strategy for laser ablation-ICP-MS microanalysis of solids and liquids", Fresenius Journal of Analytical Chemistry, 359 (1997) 390-393, DOI: 10.1007/s002160050594.

[72] B. J. Masters, B. L. Sharp, "Universal Calibration Strategy for Laser Ablation Inductively Coupled Plasma Mass Spectrometry Based on the Use of Aqueous Standards With Modified Absorption Coefficients", Analytical Communications, 34 (1997) 237-239, DOI: 10.1039/A704726F.

[73] F. Boue-Bigne, B. J. Masters, J. S. Crighton, B. L. Sharp, "A calibration strategy for LA-ICP-MS analysis employing aqueous standards having modified absorption coeficients", Journal of Analytical Atomic Spectrometry, 14 (1999) 1665-1672, DOI: 10.1039/A905479K.

[74] B. Wagner, A. Nowak, E. Bulska, J. Kunicki-Goldfinger, O. Schalm, K. Janssens, “Complementary analysis of historical glass by scanning electron microscopy with energy dispersive X-ray spectroscopy and laser ablation inductively coupled plasma mass spectrometry", Microchimica Acta, 162 (2008) 415-424, DOI: 10.1007/s00604-007-0835-7.

[75] R. Arletti, C. Giacobbe, S. Quartieri, G. Sabatino, G. Tigano, M. Triscari, G. Vezzalini, “Archaeometrical investigation of Sicilian Early Byzantine glass: chemical and spectroscopic data", Archaeometry, 52 (2010) 99-114, DOI: 10.1111/j.1475-4754.2009.00458.x.
[76] L. Dussubieux, C. M. Kusimba, V. Gogte, S. B. Kusimba, B. Gratuze, R. Oka, "The trading of ancient glass beads: new analytical data from South Asian and East African soda-alumina glass beads", Archaeometry, 50 (2008) 797-821, DOI: 10.1111/j.1475-4754.2007.00350.x.

[77] M. Bertini, A. Shortland, K. Milek, E. M. Krupp, "Investigation of Iron Age north-eastern Scottish glass beads using element analysis with LA-ICP-MS", Journal of Archaeological Science, 38 (2011) 2750-2766, DOI: 10.1016/j.jas.2011.06.019.

[78] L. Dussubieux, P. Robertshaw, M. D. Glascock, "LA-ICP-MS analysis of African glass beads: Laboratory inter-comparison with an emphasis on the impact of corrosion on data interpretation", International Journal of Mass Spectrometry, 284 (2009) 152-161, DOI: 10.1016/j.ijms.2008.11.003.

[79] A. M. de Francesco, R. Scarpelli, F. del Vecchio, D. Giampaola, "Analysis of early medieval glass from excavations at Piazza Bovio, Naples (Italy)", Archeometry, 56 (2014) 137-147, DOI: 10.1111/arcm.12070.

[80] T. Purowski, B. Wagner, E. Bulska, O. Syta, P. Dzierzanowski, "Glassy faience from the Hallstatt C period in Poland: a chemicophysical study", Journal of Archaeological Science, 50 (2014) 288-304, DOI: 10.1016/j.jas.2014.06.022.

[81] C. M. Jackson, S. Cottam, "A green thought in a green shade'; Compositional and typological observations concerning the production of emerald green glass vessels in the $1^{\text {st }}$ century A.D.", Journal of Archaeological Science, 61 (2015) 139-148, DOI: 10.1016/j.jas.2015.05.004.

[82] M. Di Bella, S. Quartieri, G. Sabatino, F. Santalucia, M. Triscari, “The glass mosaics tesserae of 'Villa del Casale' (Piazza Armerina, Italy): a multi-technique archaeometric study", Archaeological and Anthropological Sciences, 6 (2014) 345-362, DOI: 10.1007/s12520-013-0172-1.

[83] F. Gallo, A. Silvestri, G. Molin, "Glass from the Archaeological Museum of Adria (North-East Italy): new insights into Early Roman production technologies", Journal of Archaeological Science, 40 (2013) 2589-2605, DOI: 10.1016/j.jas.2013.01.017.

[84] S. Cagno, P. Cosyns, A. Izmer, F. Vanhaecke, K. Nys, K. Janssens, “Deeply colored and black-ap- 
pearing Roman glass: a continued research", Journal of Archaeological Science, 42 (2014) 128-139, DOI: 10.1016/j.jas.2013.11.003.

[85] K. Hellemans, A. Vincke, S. Cagno, D. Herremans, W. De Clercq, K. Janssens, "Composition and state of alteration of $18^{\text {th }}$-century glass finds found at the Cistercian nunnery of Clairefontaine, Belgium", Journal of Archaeological Science, 47 (2014) 121-133, DOI: 10.1016/j.jas.2014.03.039.

[86] J. J. Kunicki-Goldfinger, I. C. Freestone, I. McDonald, J. A. Hobot, H. Gilderdale-Scott, T. Ayers, "Technology, production and chronology of red window glass in the medieval period - rediscovery of a lost technology", Journal of Archaeological Science, 41 (2014) 89-105, DOI: 10.1016/j.jas.2013.07.029.

[87] V. Devulder, A. Gerdes, F. Vanhaecke, P. Degryse, "Validation of the determination of the $\mathrm{B}$ isotopic composition in Roman glasses with laser ablation multi-collector inductively coupled plasma-mass spectrometry", Spectrochimica Acta Part B, 105 (2015) 116-120, DOI: 10.1016/j.sab.2014.08.038.

[88] D. Barca, D. Miriello, A. Pecci, L. Barba, A. Ortiz, L.R. Manzanilla, J. Blancas, G.M. Crisci, "Provenance of glass shards in archaeological lime plasters by LA-ICPMS: implications for the ancient routes from the Gulf of Mexico to Teotihuacan in Central Mexico,' Journal of Archaeological Science, 40 (2013) 3999-4008, DOI: 10.1016/j.jas.2013.05.016.

[89] S. Panighello, E. F. Orsega, J. T. van Elteren, V.S. Selih, "Analysis of polychrome Iron Age glass vessels from Mediterranean I, II and III groups by LA-ICP-MS", Journal of Archaeological Science, 39 (2012) 2945-2955, DOI: 10.1016/j.jas.2012.04.043.

[90] S. Panighello, A. Kavčič, K. Vogel-Mikuš, N. H. Tennent, A. Wallert, S. B. Hočevar, J. T. van Elteren, "Investigation of smalt in cross-sections of $17^{\text {th }}$ century paintings using elemental mapping by laser ablation ICP-MS", Microchemical Journal, 125 (2016) 105-115, DOI: 10.1016/j.microc.2015.11.015.

[91] B. Siquin, Q. H. Li, F. X. Gan, "Analysis of Some Chinese Potash Glass by Laser Ablation-Inductively Coupled Plasma-Atomic Emission Spectrometry and Laser Ablation-Inductively Coupled Plasma-Mass Spectrometry", Chinese Journal of Analytical Chemistry, 41 (2013) 1328-1333, DOI: 10.1016/ S1872-2040(13)60678-7.
[92] J. T. van Elteren, N. H. Tennen, V. S. Šelih, "Multi-element quantification of ancient/historic glasses by laser ablation inductively coupled plasma mass spectrometry using sum normalization calibration", Analytica Chimica Acta, 644 (2009) 1-9, DOI: 10.1016/j.aca.2009.04.025.

[93] L. Khalidi, B. Gratuze, S. Boucetta,"Provenace of obsidian excavated from late chalcolithic levels at the sites of Tell Hamoukarand Tell Brak, Syria", Archaeometry, 51 (2009) 879-893, DOI: 10.1111/j.14754754.2009.00459.x.

[94] L. C. Kellett, M. Golitko, B. S. Bauer, "A provenance study of archaeological obsidian from the Andahuaylas region of southern Peru", Journal of Archaeological Science, 40 (2013) 1890-1902, DOI: 10.1016/j.jas.2012.11.014.

[95] C. Reepmeyer, G. Clark, "Post-colonization interaction between Vanuatu and Fiji reconsidered: the re-analysis of obsidian from Lakeba island, Fiji", Archaeometry, 52 (2010) 1-18, DOI: 10.1111/j.14754754.2009.00465.x.

[96] W. Ambrose, C. Allen, S. O'Connor, M. Spriggs, N. V. Oliveira, C. Reepmeyer, "Possible obsidian sources for artifacts from Timor: narrowing the options using chemical data", Journal of Archaeological Science, 36 (2009) 607-615, DOI: 10.1016/j. jas.2008.09.022.

[97] F.H. Brown, B.P. Nash, D.P. Fernandez, H.V. Merrick, R.J. Thomas, "Geochemical composition of source obsidians from Kenya", Journal of Archaeological Science, 40 (2013) 3233-3251, DOI: 10.1016/j.jas.2013.03.011.

[98] X. Terradas, B. Gratuze, J. Bosch, R. Enrich, X. Esteve, F. X. Oms, G. Ribé, "Neolithic diffusion of obsidian in the western Mediterranean: new data from Iberia", Journal of Archaeological Science, 41 (2014) 69-78, DOI: 10.1016/j.jas.2013.07.023.

[99] B. A. Alex, D. L. Nichols, M. D. Glascock, "Complementary compositional analysis of formative period ceramics from Teotihuacan valley", Archaeometry, 54 (2012) 821-834, DOI: 10.1111/j.14754754.2011.00652.x.

[100] H. Neff, "Analysis of Mesoamerican Plumbate Pottery Surfaces by Laser Ablation-Inductively Coupled Plasma-Mass Spectrometry (LA-ICP-MS)", 
Journal of Archaeological Science, 30 (2003) 21-35, DOI: $10.1006 /$ jasc.2001.0801.

[101] M. Golitko, J. V. Dudgeon, H. Neff, J. E. Terrell, "Identification of post-depositional chemical alteration of ceramics from the north coast of Papua New Guinea (Sanduan province) by time-offlight - laser ablation - inductively coupled plasma - mass spectrometry (TOF-LA-ICP-MS)", Archaeometry, 54 (2012) 80-100, DOI: 10.1111/j.14754754.2011.00612.x.

[102] E. E. Cochrane, H. Neff,"Investigating compositional diversity among Fijian ceramics with laser ablation-inductively coupled plasma-mass spectrometry (LA-ICP-MS): implications for interaction studies on geologically similar islands", Journal of Archaeological Science, 33 (2006) 378-390, DOI: 10.1016/j.jas.2005.08.003.

[103] J. D. Robertson, H. Neff, B. Higgins, "Microanalysis of ceramics with PIXE and LA-ICP-MS", Nuclear Instruments \& Methods in Physics Research Section B, 189 (2002) 378-381, DOI: 10.1016/S0168583X(01)01093-X.

[104] L. G. Cecil, H. Neff, "Postclassic Maya slips and paints and their relationship to socio-political groups in El Peten, Guatemala", Journal of Archaeological Science, 33 (2006) 1482-1491, DOI: 10.1016/j. jas.2006.02.005.

[105] M. Resano, J. Perez-Arantegui, E. Garcia-Ruiz, F. Vanhaecke, "Laser ablation-inductively coupled plasma mass spectrometry for the fast and direct characterization of antique glazed ceramics", Journal of Analytical Atomic Spectrometry, 20 (2005) 508-514, DOI: 10.1039/B500691K.

[106] M. Resano, P. Marzo, J. Perez-Arantegui, M. Aramendia, C. Cloquet, F. Vanhaecke, "Laser ablation-inductively coupled plasma-dynamic reaction cell-mass spectrometry for the determination of lead isotope ratios in ancient glazed ceramics for discriminating purposes", Journal of Analytical Atomic Spectrometry, 23 (2008) 1182-1191, DOI: 10.1039/b802266f.

[107] N. J. Wallis, G. D. Kamenov, "Challenges in the analysis of heterogeneous pottery by LA-ICP-MS: a comparison with INAA", Archaeometry, 55 (2013) 983-909, DOI: 10.1111/j.1475-4754.2012.00718.x.
[108] P. Van Valkenburgh, S. J. Kelloway, L. Dussubieux, J. Quilter, M. D. Glascock, "The production and circulation of indigenous lead-glazed ceramics in northern Peru during Spanish colonial times", Journal of Archaeological Science, 61 (2015) 172-185, DOI: 10.1016/j.jas.2015.06.006.

[109] A. Kreiter, D. J. Riebe, W. A. Parkinson, Á. Peto, M. Tóth, P. Pánczél, E. Bánffy, "Unique in its chaîne opératoire, unique in its symbolism: undressing a figurine from the $6^{\text {th }}$ Millennium BC Körös culture, Hungary", Journal of Archaeological Science, 44 (2014) 136-147, DOI: 10.1016/j.jas.2014.01.027.

[110] R. Scarpelli, A.M. De Francesco, M. Gaeta, D. Cottica, L. Toniolo, "The provenance of the Pompeii cooking wares: Insights from LA-ICP-MS trace element analyses", Microchemical Journal, 119 (2015) 93-101, DOI: 10.1016/j.microc.2014.11.003.

[111] P. Comodi, A. Buccianti, A. Zucchini, M. Merletti, M. Bergamini, S. Nazzareni, "Insights into the provenance of Roman moulds and poincons found at Scoppieto (Terni, Italy)", Archeometry, 56 (2014) 58-77, DOI: 10.1111/arcm.12068.

[112] L. Dussubieux, A. Deraisme, G. Frot, C. Stevenson, A. Creech, Y. Bienvenu, "LA-ICP-MS, SEM-EDS and EPMA analysis of eastern North American copper-based artefacts: impact of corrosion and heterogeneity on the reliability of the LA-ICP-MS compositional results", Archaeometry, 50 (2008) 643-657, DOI: 10.1111/j.1475-4754.2007.00367.x.

[113] L. Dussubieux, L. Van Zelst, "LA-ICP-MS analysis of platinum-group elements and other elements of interest in ancient gold", Applied Physics A, 79 (2004) 353-356, DOI: 10.1007/s00339-004-2532-2.

[114] M. F. Guerra, T. Calligaro, "Gold traces to trace gold”, Journal of Archaeological Science, 31 (2004) 1199-1208, DOI: 10.1016/j.jas.2002.05.001.

[115] M. Resano, M. P. Marzo, R. Alloza, C. Saenz, F. Vanhaecke, L. Yang, S. Willie, R. E. Sturgeon, "Laser ablation single-collector inductively coupled plasma mass spectrometry for lead isotopic analysis to investigate evolution of the Bilbilis mint", Analytica Chimica Acta, 677 (2010) 55-63, DOI: 10.1016/j. aca.2010.07.032.

[116] E. E. Cochrane, H. Neff,"Investigating compositional diversity among Fijian ceramics with laser 
ablation-inductively coupled plasma-mass spectrometry (LA-ICP-MS): implications for interaction studies on geologically similar islands", Journal of Archaeological Science, 33 (2006) 378-390, DOI: 10.1016/j.jas.2005.08.003.

[117] C. Bendall, D. Wigg-Wolf, Y. Lahaye, H. M. Von Kaenel, G. P. Brey, "Detecting changes of Celtic gold sources through the application of trace element and $\mathrm{Pb}$ isotope laser ablation analysis of Celtic gold coins", Archaeometry, 51 (2009) 598-625, DOI: 10.1111/j.1475-4754.2008.00423.x.

[118] V. Lyubomirova, R. Djingova, I. Kuleff, "Comparison of analytical techniques for analysis of archaeological bronze", Archaeometry, 57 (2015) 677-686, DOI: 10.1111/arcm.12138.

[119] D. Walaszek, M. Senn, A. Wichser, M. Faller, B. Wagner, E. Bulska, A. Ulrich, "Minimally-invasive Laser Ablation Inductively Coupled Plasma Mass Spectrometry analysis of model ancient copper alloys", Spectrochimica Acta Part B, 99 (2014) 115-120, DOI: 10.1016/j.sab.2014.06.023.

[120] L. Dussubieux, H. Walder, "Identifying American native and European smelted coppers with pXRF: a case study of artifacts from the Upper Great Lakes region", Journal of Archaeological Science, 59 (2015) 169-178, DOI: 10.1016/j.jas.2015.04.011.

[121] L. C. Giannossa, S. Loperfido, M. Caggese, G. E. De Benedetto, R. Laviano, L. Sabbatini, A. Mangone, "A systematic characterization of fibulae from Italy: from chemical composition to microstructure and corrosion processes", New Journal of Chemistry, 37 (2013) 1238-1251, DOI: 10.1039/c2nj40362e.

[122] F. Nocete, R. Sáez, M.R. Bayona, J.M. Nieto, A. Peramo, P. López, J.I. Gil-Ibarguchi, N. Inácio, S. García, J. Rodríguez, "Gold in the Southwest of the Iberian Peninsula during the 3rd Millennium BC", Journal of Archaeological Science, 41 (2014) 691-704, DOI: 10.1016/j.jas.2013.10.006.

[123] V. Mozna, J. Pisonero, M. Hola, V. Kanicky, D. Günther, "Quantitative analysis of Fe-based samples using ultraviolet nanosecond and femtosecond laser ablation-ICP-MS", Journal of Analytical Atomic Spectrometry, 21 (2006) 1194-1201, DOI: 10.1039/ B606988F.
[124] B. Zhian, Y. Wenting, Y. Honglin, L. Xu, C. Kaiyun, Z. Chunlei, "Non-matrix-matched determination of lead isotope ratios in ancient bronze artifacts by femtosecond laser ablation multi-collector inductively coupled plasma mass spectrometry", International Journal of Mass Spectrometry, 402 (2016) 12-19, DOI: 10.1016/j.ijms.2016.03.001.

[125] A. Cucina, J. Dudgeon, H. Neff,"Methodological strategy for the analysis of human dental enamel by LA-ICP-MS", Journal of Archaeological Science, 34 (2007) 1884-1888, DOI: 10.1016/j.jas.2007.01.004.

[126] J. Farell, D. Amarasiriwardena, A. H. Goodman, B. Arriaza, "Bioimaging of trace metals in ancient Chilean mummies and contemporary Egyptian teeth by laser ablation-inductively coupled plasma-mass spectrometry (LA-ICP-MS)", Microchemical Journal, 106 (2013) 340-346, DOI: 10.1016/j.microc.2012.09.005.

[127] L. Bartkus, D. Amarasiriwardena, B. Arriaza, D. Bellis, J. Yanez, "Exploring lead exposure in ancient Chilean mummies using a single strand of hair by laser ablation-inductively coupled plasma-mass spectrometry (LA-ICP-MS)", Microchemical Journal, 98 (2011) 267-274, DOI: 10.1016/j.microc.2011.02.008.

[128] M. Willmes, L. Kinsley, M. H. Moncel, R. A. Armstrong, M. Aubert, S. Eggins, R. Grün, "Improvement of laser ablation in situ micro-analysis to identify diagenetic alteration and measure strontium isotope ratios in fossil human teeth", Journal of Archaeological Science, 70 (2016) 102-116, DOI: 10.1016/j.jas.2016.04.017.

[129] D. Barca, C. M. Belfiore, G. M. Crisci, M. F. La Russa, A. Pezzina, S. A. Ruffolo, "A new methodological approach for the chemical characterization of black crusts on building stones: a case study from the Catania city centre (Sicily, Italy)", Journal of Analytical Atomic Spectrometry, 26 (2011) 1000-1011, DOI: $10.1039 /$ C0JA00226G.

[130] L. Moreau, M. Brandl, P. Filzmoser, C. Hauzenberger, E. Goemaere, I. Jadin, H. Collet, A. Hauzeur, R. W. Schmitz, "Geochemical Sourcing of Flint Artifacts from Western Belgium and the German Rhineland: Testing Hypotheses on Gravettian Period Mobility and Raw Material Economy", Geoarchaeology: An International Journal, 31 (2016) 229-243, DOI: 10.1002/gea.21564. 
[131] S. A. Ruffolo, V. Comite, M. F. La Russa, C. M. Belfiore, D. Barca, A. Bonazza, G. M. Crisci, A. Pezzino, C. Sabbioni, "An analysis of the black crusts from the Seville Cathedral: A challenge to deepen the understanding of the relationships among microstructure, microchemical features and pollution sources", Science of the Total Enviroment, 502 (2015) 157-166, DOI: 10.1016/j.scitotenv.2014.09.023.

[132] A. A. Evans, Y. B. Wolframm, R. E. Donahue, W. A. Lovis, "The phytolith archaeological record: strengths and weaknesses evaluated based on a quantitative modern reference collection from Greece", Journal of Archaeological Science, 34 (2007) 2161-2169, DOI: 10.1016/j.jas.2006.10.017.

[133] D. Miriello, D. Barca, A. Pecci, R. de Luca, G. M. Crisci, "Plasters from different buildings of the sacred precinct of Tenochtitlan (Mexico City): characterization and provenance", Archaeometry, 57 (2015) 100-127, DOI: 10.1111/arcm.12074.

[134] F. Cattin, B. Guenette-Beck, P. Curdy, N. Meisser, S. Ansermet, B. Hofmann, R. Kuendig, V. Hubert, M. Woerle, K. Hametner, D. Guenther, A. Wichser, A. Ulrich, I. M. Villa, M. Besse, "Provenance of Early Bronze Age metal artefacts in Western Switzerland using elemental and lead isotopic compositions and their possible relation with copper minerals of the nearby Valais", Journal of Archaeological Science, 38 (2011) 1221-1233, DOI: 10.1016/j. jas.2010.12.016.

[135] V. Van der Linden, P. Cosyns, O. Schalm, S. Cagno, K. Nys, K. Janssens, A. Nowak, B. Wagner, E. Bulska, "Deeply coloured and black glass in the northern provinces of the Roman Empire: differences and similarities in chemical composition befora and after AD 150", Archaeometry, 51 (2009) 822-844, DOI: 10.1111/j.1475-4754.2008.00434.x.

[136] L. Dussubieux, in Archaeological Chemistry: Analytical Techniques and Archaeological Interpretation, M. D. Glascok, R. J. Speakman, R. S. Popelka Filcoff (Eds.), 968 (2007) 336-348.

[137] B. Wagner, A. Nowak, E. Bulska, K. Hametner, D. Guenther, "Critical assessment of the elemental composition of Corning archeological reference glasses by LA-ICP-MS", Analytical and Bioanalytical Chemistry, 402 (2012) 1667-1677, DOI: 10.1007/ s00216-011-5597-8.
[138] M. Pakiela, M. Wojciechowski, B. Wagner, E. Bulska, "A novel procedure of powdered samples immobilization and multi-point calibration of LA ICP MS", Journal of Analytical Atomic Spectrometry, 26 (2011) 1539-1543, DOI: 10.1039/C0JA00201A.

[139] P. Budd, J. Montgomery, A. Cox, P. Krause, B. Barreiro, R. G. Thomas, "The distribution of lead within ancient and modern human teeth: Implications for long-term and historical exposure monitoring", Science of Total Environment, 220 (1998) 121-136, DOI: 10.1016/S0048-9697(98)00244-7.

[140] D. Gunther, A. von Quadt, R. Wirz, H. Cousin, V. J. Dietrich, "Elemental Analyses Using Laser Ablation-Inductively Coupled Plasma-Mass Spectrometry (LA-ICP-MS) of Geological Samples Fused with Li2B4O7 and Calibrated Without Matrix-Matched Standards", Microchimica Acta, 136 (2001) 101-107, DOI: $10.1007 / \mathrm{s} 006040170038$.

[141] H. P. Longerich, S. E. Jackson, D. Gunther, "Laser Ablation Inductively Coupled Plasma Mass Spectrometric Transient Signal Data Acquisition and Analyte Concentration Calculation", Journal of Analytical Atomic Spectrometry, 11 (1996) 899-904, DOI: 10.1039/JA9961100899.

[142] B. Gratuze, "Obsidian Characterization by Laser Ablation ICP-MS and its Application to Prehistoric Trade in the Mediterranean and the Near East: Sources and Distribution of Obsidian within the Aegean and Anatolia", Journal of Archaeological Science, 26 (1999) 869-881, DOI: 10.1006/ jasc.1999.0459.

[143] Y. Liu, Z. Hu, S. Gao, D. Guenther, J. Xu, C. Gao, H. Chen, "In situ analysis of major and trace elements of anhydrous minerals by LA-ICP-MS without applying an internal standard", Chemical Geology, 257 (2008) 34-43, DOI: 10.1016/j.chemgeo.2008.08.004.

[144] D. Barca, A. M. De Francesco, G. M. Crisci, "Chemical and mineralogical examination of metallurgical ceramics from a Late Bronze Age copper smelting site in Cyprus", Journal of Cultural Heritage, 34 (2007) 141-150, DOI: 10.1016/j.jas.2006.04.005.

[145] M. I. Szynkowska, K. Czerski, T. Paryjczak, E. Rybicki, A. Wlochowicz, “Testing Textiles Using the LA-ICP-MS-TOF Method", Fibres \& Textiles in Eastern Europe, 14 (2006) 87-90. 
[146] G. Sarah, B. Gratuze, J.-N. Barrandon, "Application of laser ablation inductively coupled plasma mass spectrometry (LA-ICP-MS) for the investigation of ancient silver coins", Journal of Analytical Atomic Spectrometry, 22 (2007) 1163-1167, DOI: 10.1039/B704879C.

[147] V. S. Selih, J. T. van Elteren, "Quantitative multi-element mapping of ancient glass using a simple and robust LA-ICP-MS rastering procedure in combination with image analysis", Analytical and Bioanalytical Chemistry, 401 (2011) 745-755, DOI: 10.1007/s00216-011-5119-8.

[148] M. Bertini, A. Izmer, F. Vanhaecke, E. M. Krupp, "Critical evaluation of quantitative methods for the multi-elemental analysis of ancient glasses using laser ablation inductively coupled plasma mass spectrometry", Journal of Analytical Atomic Spectrometry, 28 (2013) 77-91, DOI: 10.1039/C2JA30036B.

[149] D. Walaszek, M. Senn, M. Faller, L. Philippe, B. Wagner, E. Bulska, A. Ulrich, "Metallurgical and chemical characterization of copper alloy reference materials within laser ablation inductively coupled plasma mass spectrometry: method development for minimally-invasive analysis of ancient bronze objects", Spectrochimica Acta Part B, 79-80 (2013) 17-30, DOI: 10.1016/j.sab.2012.11.001.

[150] M. S. Walton, A. Shortland, S. Kirk, P. Degryse, "Evidence for the trade of Mesopotamian and Egyptian glass to Mycenaean Greece", Journal of Archaeological Science, 36 (2009) 1496-1503, DOI: 10.1016/j.jas.2009.02.012.

[151] J. Wouters, "Protecting Cultural Heritage. Reflections on the Position of Science in Multidisciplinary Approaches", Chemistry International, 30 (2008) 4-8, https://www.iupac.org/publications/ ci/2008/3001/1_wouters.html (accessed 14.10.2016).

[152] K. Smith, K. Horton, R. J. Watling, N. Scoullar, "Detecting art forgeries using LA-ICP-MS incorporating the in situ application of laser-based collection technology", Talanta, 67 (2005) 402-413, DOI: 10.1016/j.talanta.2005.06.030.

[153] P. Arrowsmith, S. K. Hughes, "Entrainment and Transport of Laser Ablated Plumes for Subsequent Elemental Analysis", Applied Spectroscopy, 42 (1988) 1231-1239, DOI: 10.1366/0003702884430100.
[154] C. C. Garcia, H. Lindner, K. Niemax, "Transport efficiency in femtosecond laser ablation inductively coupled plasma mass spectrometry applying ablation cells with short and long washout times", Spectrochimica Acta Part B, 62 (2007) 13-19, DOI: 10.1016/j.sab.2006.11.005.

[155] D. Autrique, A. Bogaerts, H. Lindner, C. C. Garcia, K. Niemax, "Design analysis of a laser ablation cell for inductively coupled plasma mass spectrometry by numerical simulation", Spectrochimica Acta Part B, 63 (2008) 257-270, DOI: 10.1016/j. sab.2007.11.032.

[156] J. Pisonero, D. Fliegel, D. Guenther, "High efficiency aerosol dispersion cell for laser ablation-ICP-MS", Journal of Analytical Atomic Spectrometry, 21 (2006) 922-931, DOI: 10.1039/ B603867K.

[157] E. Marin, A. Padró, A. Miquel, J. F. Garcia, "Characterization of Paintings by Laser Ablation-Inductively Coupled Plasma-Mass Spectrometry", Analytical Letters, 48 (2015) 167-179, DOI: 10.1080/00032719.2014.921823.

[158] M. Aubert, I. S. Williams, K. Boljkovac, I. Moffat, M.-H. Moncel, E. Dufour, R. Gruen, "In situ oxygen isotope micro-analysis of faunal material and human teeth using a SHRIMP II: a new tool for palaeo-ecology and archaeology", Journal of Archaeological Science, 39 (2012) 3184-3194, DOI: 10.1016/j.jas.2012.05.002.

[159] A. Simonetti, M. R. Buzon, R. A. Creaser, "Insitu elemental $\mathrm{Sr}$ isotope investigation of human tooth enamel by laser ablation-(MC)-ICP-MS: successes and pitfalls", Archaeometry, 50 (2008) 371-385, DOI: 10.1111/j.1475-4754.2007.00351.x.

[160] C. L. King, N. Tayles, K. C. Gordon, "Re-examining the chemical evaluation of diagenesis in human bone apatite", Journal of Archaeological Science, 38 (2011) 2222-2230, DOI: 10.1016/j.jas.2011.03.023.

[161] M. Gil, R. Green, M. L. Carvalho, A. Seruya, I. Queralt, A. E. Candeias, J. Mirao, "Rediscovering the palette of Alentejo (Southern Portugal) earth pigments: provenance establishment and characterization by LA-ICP-MS and spectra-colorimetric analysis", Applied Physics A, 96 (2009) 997-1007, DOI: $10.1007 / \mathrm{s} 00339-009-5134-1$. 
[162] K. Polikreti, C. Christofides, "Composition profiles and time evolution of buried marble patinas by LA-ICP-MS and laser-induced micro-photo-luminescence", Archaeometry, 52 (2010) 937-948, DOI: 10.1111/j.1475-4754.2010.00531.x.

[163] J. Baker, S. Stos, T. Waight, "Lead isotope analysis of archaeological metals by multiple-collector inductively coupled plasma mass spectrometry", Archaeometry, 48 (2006) 45-56, DOI: 10.1111/j.14754754.2006.00242.x.

[164] M. Ponting, J. A. Evans, V. Pashley, "Fingerprinting of Roman mints using laser-ablation MC-ICP-MS lead isotope analysis", Archaeometry, 45 (2003) 591-597, DOI: 10.1046/j.14754754.2003.00130.x.

[165] T. Carter, G. Poupeau, C. Bressy, N. J. G. Pearce, "A new programme of obsidian characterization at Catalhoyuk, Turkey" Journal of Archaeological Science, 33 (2006) 893-909, DOI: 10.1016/j. jas.2005.10.023.

[166] S. Panighello, E. F. Orsega, J. T. van Elteren, V.S.Selih, "Analysis of polychrome Iron Age glass vessels from Mediterranean I, II and III groups by LA-ICP-MS", Journal of Archaeological Science, 39 (2012) 2945-2955, DOI: 10.1016/j.jas.2012.04.043.

[167] N. Schibille, "Late Byzantine Mineral Soda High Alumina Glasses from Asia Minor: A New Primary Glass Production Group", Plos One, 6 (2011), DOI: 10.1371/journal.pone.0018970.

[168] Y. Su, L. Qu, H. Duan, N. Tarcea, A. Shen, J. Popp, J. Hu, "Elemental analysis-aided Raman spectroscopic studies on Chinese cloisonné wares and painted enamels from the Imperial Palace", Spectrochimica Acta Part A, 153 (2016) 165-170, DOI: 10.1016/j.saa.2015.08.005.

[169] M. Walton, K. Eremin, A. Shortland, P. Degryse, S. Kirk, "Analysis of late Bronze Age glass axes from Nippur - a new cobalt colourant", Archaeometry, 54 (2012) 835-852, DOI: 10.1111/j.14754754.2012.00664.x.

[170] S. Schlosser, A. Reinecke, R. Schwab, E. Pernicka, S. Sonetra, V. Laychour, "Early Cambodian gold and silver from Prohear: composition, trace elements and gilding", Journal of Archaeological Science, 39 (2012) 2877-2887, DOI: 10.1016/j.jas.2012.04.045.
[171] B. Arriaza, D. Amarasiriwardena, L. Cornejo, V. Standen, S. Byrne, L. Bartkus, B. Bandak, "Exploring chronic arsenic poisoning in pre-Columbian Chilean mummies", Journal of Archaeological Science, 37 (2010) 1274-1278, DOI: 10.1016/j.jas.2009.12.030.

[172] S. Byrne, D. Amarasiriwardena, B. Bandak, L. Bartkus, J. Kane, J. Jones, J. Yanez, B. Arriaza, L. Cornejo, "Were Chinchorros exposed to arsenic? Arsenic determination in Chinchorro mummies' hair by laser ablation inductively coupled plasma-mass spectrometry (LA-ICP-MS)", Microchemical Journal, 94 (2010) 28-35, DOI: 10.1016/j.microc.2009.08.006.

[173] S. R. Copeland, M. Sponheimer, J. A. LeeThorp, P. J. le Roux, D. J. de Ruiter, M. P. Richards, "Strontium isotope ratios in fossil teeth from South Africa: assessing laser ablation MC-ICP-MS analysis and the extent of diagenesis", Journal of Archaeological Science, 37 (2010) 1437-1446, DOI: 10.1016/j. jas.2010.01.003.

[174] O. Syta, K. Rozum, M. Choińska, D. Zielińska, G. Z. Żukowska, A. Kijowska, B. Wagner, "Analytical procedure for characterization of medieval wall-paintings by X-ray fluorescence spectrometry, laser ablation inductively coupled plasma mass spectrometry and Raman spectroscopy", Spectrochimica Acta Part B, 101 (2014) 140-148, DOI: 10.1016/j. sab.2014.08.003.

[175] D. Asogan, B. L. Sharp, C. J. P. O'Connor, D. A. Green, R. W. Hutchinson, "An open, non-contact cell for laser ablation-inductively coupled plasma-mass spectrometry", Journal of Analytical Atomic Spectrometry, 24 (2009) 917-923, DOI: 10.1039/B904850B.

[176] M. B. Fricker, D. Kutscher, B. Aeschlimann, J. Frommer, R. Dietiker, J. Bettmer, D. Guenther, "High spatial resolution trace element analysis by LA-ICP-MS using a novel ablation cell for multiple or large samples", International Journal of Mass Spectrometry, 307 (2011) 39-45, DOI: 10.1016/j. ijms.2011.01.008.

[177] R. Glaus, J. Koch, D. Guenther, "Portable Laser Ablation Sampling Device for Elemental Fingerprinting of Objects Outside the Laboratory with Laser Ablation Inductively Coupled Plasma Mass Spectrometry", Analytical Chemistry, 84 (2012) 5358-5364, DOI: 10.1021/ac3008626. 
[178] L. Dorta, R. Kovacs, J. Koch, K. Nishiguchi, K. Utani, D. Günther, "Determining isotope ratios using laser ablation sampling in air with MC-ICPMS", Journal of Analytical Atomic Spectrometry, 28 (2013) 1513-1521, DOI: 10.1039/C3JA50126D.

[179] D. Barca, D. Miriello, A. Pecci, L. Barba, A. Ortiz, L. R. Manzanilla, J. Blancas, G. M. Crisci, "Provenance of glass shards in archaeological lime plasters by LA-ICP-MS: implications for the ancient routes from the Gulf of Mexico to Teotihuacan in Central Mexico", Journal of Archaeological Science, 40 (2013) 3999-4008, DOI: 10.1016/j. jas.2013.05.016.

[180] J. T. van Elteren, A. Izmer, M. Sala, E. F. Orsega, V.S. Selih, S. Panighello, F. Vanhaecke, "3D laser ablation-ICP-mass spectrometry mapping for the study of surface layer phenomena - a case study for weathered glass", Journal of Analytical Atomic Spectrometry, 28 (2013) 994-1004, DOI: 10.1039/ c3ja30362d.

[181] S. Panighello, E. F. Orsega, J. T. van Elteren, V.S. Selih, "Analysis of polychrome Iron Age glass vessels from Mediterranean I, II and III groups by LA-ICP-MS”, Journal of Archaeological Science, 39 (2012) 2945-2955, DOI: 10.1016/j.jas.2012.04.043.

[182] D. Barca, E. Basso, D. Bersani, G. Galli, C. Invernizzi, M. F. La Russa, P. P. Lottici, M. Malagodi, S. A. Ruffolo, "Vitreous tesserae from the calidarium mosaics of the Villa dei Quintili, Rome. Chemical composition and production technology", Microchemical Journal, 124 (2016) 726-735, DOI: 10.1016/j.microc.2015.10.037.

[183] W. Devos, M. Senn-Luder, C. Moor, C. Salter, "Laser ablation inductively coupled plasma mass spectrometry (LA-ICP-MS) for spatially resolved trace analysis of early-medieval archaeological iron finds", Fresenius Journal of Analytical Chemistry, 366 (2000) 873-880, DOI: 10.1007/s002160051588.

[184] T. Purowski, P. Dzierzanowski, E. Bulska, B. Wagner, A. Nowak, "A study of glass beads from the Hallstatt C-D from southwestern Poland: implications for glass technology and provenance", Archaeometry, 54 (2012) 144-166, DOI: 10.1111/j.1475-4754.2011.00619.x.

[185] J. Henderson, S. Chenery, E. Faber, J. Kröger, "The use of electron probe microanalysis and laser ablation-inductively coupled plasma-mass spectrometry for the investigation of $8^{\text {th }}-14^{\text {th }}$ century plant ash glasses from the Middle East", Microchemical Journal, 128 (2016) 134-152, DOI: 10.1016/j.microc.2016.03.013.

[186] R. Bugoi, B. Constantinescu, C. Neelmeijer, F. Constantin, "The potential of external IBA and LA-ICP-MS for obsidian elemental characterization", Nuclear Instruments \& Methods in Physics Research Section B, 226 (2004) 136-146, DOI: 10.1016/j. nimb.2004.04.185.

[187] Z. Šmit, T. Milavec, H. Fajfar, T. Rehren, J.W. Lankton, B. Gratuze, "Analysis of glass from the post-Roman settlement Tonovcov gra (Slovenia) by PIXE-PIGE and LA-ICP-MS", Nuclear Instruments and Methods in Physics Research B, 311 (2013) 53-59, DOI: 10.1016/j.nimb.2013.06.012.

[188] C. M. Sinopoli, Dueppen, S., Brubaker, R., Descantes, C., Glascock, M.D., Griffin, W., Neff, H., Shoocongdej, R., Speakman, R.J., "Characterizing the Stoneware 'Dragon Jars' in the Guthe Collection: Chemical, Decorative, and Formal Patterning", Asian Perspectives, 45 (2006) 240-282, DOI: 10.1353/ asi.2006.0026.

[189] A. B. Stahl, M. d. D. Cruz, H. Neff, M. D. Glascock, R. J. Speakman, B. Giles, L. Smith, "Ceramic production, consumption and exchange in the Banda area, Ghana: Insights from compositional analyses", Journal of Anthropological Archaeology, 27 (2008) 363-381, DOI: 10.1016/j.jaa.2008.04.001.

[190] R. Liu, H. Zhou, L. Zhang, Z. Zhong, W. Zeng, H. Xiang, S. Jin, X. Lu, C. Li, "Paleoproterozoic reworking of ancient crust in the Cathaysia Block, South China: Evidence from zircon trace elements, $\mathrm{U}-\mathrm{Pb}$ and $\mathrm{Lu}-\mathrm{Hf}$ isotopes", Chinese Science Bulletin, 54 (2009) 1543-1554, DOI: 10.1007/s11434-0090096-4.

[191] M. F. Guerra, "The circulation of South American precious metals in Brazil at the end of the $17^{\text {th }}$ century", Journal of Archaeological Science, 31 (2004) 1225-1236, DOI: 10.1016/j.jas.2004.03.018.

[192] L. G. Cecil, "Central Peten blue pigment: A maya blue source outside of Yucatan, Mexico", Journal of Archaeological Science, 37 (2010) 1006-1019, DOI: 10.1016/j.jas.2009.12.001. 
[193] S. Leroy, R. Simon, L. Bertrand, A. Williams, E. Foy, P. Dillmann, "First examination of slag inclusions in medieval armours by confocal SR- $\mu$ XRF and LA-ICP-MS", Journal of Analytical Atomic Spectrometry, 26 (2011) 1078-1087, DOI: 10.1039/ C0JA00261E.

[194] C. L. King, N. Tayles, K. C. Gordon, "Re-examining the chemical evaluation of diagenesis in human bone apatite", Journal of Archaeological Science, 38 (2011) 2222-2230, DOI: 10.1016/j.jas.2011.03.023.

[195] L. Rampazzi, B. Rizzo, C. Colombo, C. Conti, M. Realini, U. Bartolucci, M. P. Colombini, A. Spiriti,
L. Facchin, "The stucco decorations from St. Lorenzo in Laino (Como, Italy): The materials and the techniques employed by the "Magistri Comacini"', Analytica Chimica Acta, 630 (2008) 91-100, DOI: 10.1016/j.aca.2008.09.052.

[196] R. Glaus, L. Dorta, Z. Zhang,Q. Ma, H. Berke, D. Günther, "Isotope ratio determination of objects in the field by portable laser ablation sampling and subsequent multicollector ICPMS", Journal of Analytical Atomic Spectrometry, 28 (2013) 801-809, DOI: 10.1039/C3JA30379A. 